\title{
A GARANTIA CONSTITUCIONAL DO CONTRADITÓRIO NO NOVO CÓDIGO DE PROCESSO CIVIL
}

\author{
Guglielmo Marconi Soares de Castro ${ }^{138}$
}

Recebido em: 02/09/2016

Aprovado em: 23/09/2016

\begin{abstract}
RESUMO
O presente artigo examina a garantia constitucional do contraditório, tal como restou conformada no âmbito do novo Código de Processo Civil brasileiro, perpassando, como antecedente necessário, pela análise dos escopos principais que animaram a atuação reformadora do legislador em face do estatuto instrumental civil de 1973. Expor-se-á, em seguida, acerca dos contornos teóricos até então atribuídos ao referido princípio constitucional na seara cível, descrevendo, por fim, não sem a emissão de um juízo crítico decorrente das primeiras impressões que o tema suscita, as alterações mais relevantes e substanciais implementadas pela Lei $n^{\circ} 13.105 / 15$, ao instituir o contraditório dinâmico, como garantia de influência e não surpresa, no novel sistema processual.
\end{abstract}

Palavras-chave: Contraditório. Garantia de influência. Não surpresa. Novo Código de Processo Civil brasileiro.

\section{AS RAZÕES PARA A FORMULAÇÃO DE UM NOVO SISTEMA PROCESSUAL CIVIL}

É histórico o descontentamento dos brasileiros com a qualidade dos serviços que lhes são ofertados a título de prestação jurisdicional na seara cível, por inúmeros motivos, dentre os quais podemos destacar a indisfarçável morosidade, a escassa efetividade e os elevados custos do processo, para citar somente os mais emblemáticos.

Alguns enxergam como principais causas para tais problemas a pronunciada cultura do litígio, outros a quantidade excessiva de recursos admissíveis em nosso Direito Processual Civil, assim como as deficiências estruturais e de pessoal do Poder Judiciário em relação ao volume crescente de trabalho, ou mesmo aspectos relacionados à produtividade funcional de juízes e servidores.

\footnotetext{
${ }^{138}$ Promotor de Justiça no Estado do Rio Grande do Norte. Bacharel em Direito pela UERN. Especialista em Direito Constitucional pela UNISUL. Mestre em Direito Constitucional pela UFRN.
} 
Essas certamente seriam justificativas bastantes para, sem ignorar a atuação fiscalizadora e de controle que vem sendo desenvolvida no âmbito do Conselho Nacional de Justiça com vistas ao aprimoramento dos trabalhos judiciários, ensejar uma reforma legislativa de vários de nossos institutos processuais, porém sem necessariamente implicar na edição de um novo Código de Processo Civil (CPC).

De fato, questiona-se se a legislação instrumental vigente, gestada em 1973, de reconhecida qualidade técnica, fruto do labor científico creditado ao Ministro Alfredo Buzaid, sob profunda influência do escólio de Liebman, ${ }^{139}$ não poderia ter simplesmente continuado a viger e a receber as reformas, mais ou menos profundas, que porventura se mostrassem necessárias como resposta às novas demandas de nossa sociedade, no espírito das sucessivas alterações aperfeiçoadoras ocorridas, especialmente, no interregno situado entre os anos de 1994 e 2010, vocacionadas, em grande medida, à implementação de maior efetividade processual, na linha da terceira onda renovatória do acesso à justiça. ${ }^{140}$

Parte considerável da doutrina, aliás, vinha sustentando que, mais do que um novo Código de Processo Civil, o ordenamento jurídico pátrio clama por uma mudança de mentalidade da parte dos seus operadores, a fim de moldar a prática processual processual civil às "necessidades substanciais carentes de tutela e aos direitos fundamentais", ${ }^{141}$ conformandoa ao modelo de processo constitucional exigido pelo Estado Democrático de Direito, em real consonância com as necessidades reclamadas pela complexidade do mundo contemporâneo. ${ }^{142}$

Com a intensificação dos debates acerca do tema no Congresso Nacional, contudo, vieram a tona argumentos potencialmente legitimadores da promoção de significativas modificações em nossa legislação processual civil, buscando adequá-la às mudanças jurídicas, tecnológicas e sociais havidas desde a edição do Código de 1973, como o caráter normativo adquirido pelos princípios jurídicos, o papel criativo que a função jurisdicional passou a assumir na formação do Direito, a massificação dos conflitos e o advento de meios eletrônicos para a veiculação e documentação de atos processuais, apenas para exemplificar, a demandar a formulação de soluções inovadoras para a nossa cultura jurídica. ${ }^{143}$

139 GRINOVER, Ada Pellegrini. O magistério de Enrico Tullio Liebman no Brasil. Revista da Faculdade de Direito da Universidade de São Paulo. São Paulo: Universidade de São Paulo, 1986, v. 1, p. 98-102.

140 CAPPELlETTI, Mauro; GARTH, Bryant. Acesso à justiça. Trad. Ellen Gracie Northfleet. Porto Alegre: Sérgio Antonio Fabris Editor, 1988.

141 MARINONI, Luiz Guilherme. Idéias para um renovado direito processual. In: CARNEIRO, Athos Gusmão. CALMON, Petrônio (org.). Bases científicas para um renovado direito processual. 2 ed. Salvador: Jus Podium, 2009, p. 125-146.

142 BUENO, Cassio Scarpinella. Bases para um pensamento contemporâneo do direito processual civil. In: CARNEIRO, Athos Gusmão. CALMON, Petrônio (org.). Op. cit., p. 375-386.

143 DIDIER JÚNIOR, Fredie. Razões para um novo CPC: confiteor. Disponível em: <http://www.frediedidier.com.br/editorial/editorial-151/>. Acesso em: 05 jun. 2015. 
Proclamado o novo CPC, evidencia o seu texto final que, mesmo com as alterações surgidas no curso do processo legislativo, sobretudo na Câmara dos Deputados, não houve grandes rupturas com o desenho geral do Código Buzaid, tal como foi expressamente reconhecido na própria Exposição de Motivos do Anteprojeto, consignando-se, na oportunidade, que, "além de conservados os institutos cujos resultados foram positivos, incluíram-se no sistema outros tantos que visam a atribuir-lhe alto grau de eficiência". ${ }^{144}$

Os objetivos perseguidos pela comissão de juristas que se dedicou à elaboração do referido anteprojeto foram sintetizados em cinco, a saber: 1) estabelecer uma maior sintonia com as normas da Constituição Federal; 2) criar condições para que o juiz possa decidir de forma "mais rente à realidade fática subjacente à causa"; 3) reduzir a complexidade de subsistemas, como o recursal, para, com isso, solucionar problemas; 4) conferir o maior rendimento possível a cada processo; e 5) conceder mais organicidade ao sistema, dando-lhe maior coesão. ${ }^{145}$

Como uma das soluções adotadas para atingir, a um só tempo, parte considerável desses objetivos, resolveu-se repensar a forma de incidência do princípio do contraditório no processo civil, ao instituir regras consubstanciadoras de uma "garantia processual de influência e não surpresa para a formação de decisões", ${ }^{146}$ em oposição a uma concepção meramente formal do mencionado princípio, tradicionalmente compreendido como um simples direito de informação e reação.

Resta saber, todavia, em que medida tais substratos teóricos constituem autêntica novidade trazida pela nova legislação para o nosso sistema processual, bem como, os benefícios e os possíveis impactos que as futuras regras processuais atinentes ao exercício do contraditório virão acarretar para a celeridade, a eficiência e a economicidade no processo civil.

\section{O CONTRADITÓRIO NO CPC DE 1973}

O princípio do contraditório consiste em garantia ínsita à cláusula do devido processo legal, como pressuposto inarredável de um processo justo, motivo pelo qual não necessitaria

\footnotetext{
144 BRASIL. Congresso Nacional. Senado Federal. Comissão de Juristas. Anteprojeto do novo Código de Processo Civil. Brasília: Senado Federal, 2010, p. 13. Disponível em: <http://www.senado.gov.br/senado/novocpc/pdf/Anteprojeto.pdf $>$. Acesso em: 05 jun. 2015. 145 . Op. cit, p. 14.

146 THEODORO JÚNIOR, Humberto; NUNES, Dierle; BAHIA, Alexandre Melo Franco; PEDRON, Flávio Quinaud. Novo CPC: fundamentos e sistematização. 2. ed. Rio de Janeiro: Forense, 2015, p. 92-94.
} 
sequer, para alguns autores, estar expressamente previsto em nosso ordenamento constitucional, bastando a menção à garantia do due process of law, para que estivesse implicitamente contemplado, juntamente com outros princípios constitucionais do processo, como o do juiz natural e o da proibição de provas ilícitas. ${ }^{147}$

Compreendido na estrita acepção de bilateralidade da audiência, referido princípio significaria, na essência, o direito do réu ao conhecimento quanto à existência do pedido formulado em juízo em seu desfavor, bem como, de ciência acerca dos atos processuais subsequentes, extensível aos demais integrantes da relação processual, com a garantia de possível reação contra decisões desfavoráveis. ${ }^{148}$

Não é de hoje, porém, a advertência doutrinária no sentido da insuficiência conceitual do contraditório como mero postulado de informação necessária e reação facultada, alertandose, de há muito, que

[...] as partes, em relação ao juiz, não têm papel de antagonistas, mas sim de 'colaboradores necessários': cada um dos contendores age no processo tendo em vista o próprio interesse, mas a ação combinada dos dois serve à justiça na eliminação do conflito ou controvérsia que os envolve. ${ }^{149}$ (Grifo nosso).

Já apregoava Carlos Alberto de Oliveira, ainda na primeira década de vigência da Constituição de 1988, a necessidade de se passar a compreender o contraditório como uma verdadeira divisão de trabalho, no processo, entre os distintos sujeitos que o compõem, mediante colaboração e diálogo permanentes entre juiz, autor e réu, enaltecendo-se o direito da parte "de atuar de modo crítico e construtivo sobre o andamento do processo e o seu resultado", em repúdio a uma investigação solitária do juiz acerca da matéria constitutiva do objeto da demanda. ${ }^{150}$

De igual modo, registra Rui Portanova que o processo democrático pressupõe a participação do jurisdicionado na preparação do ato de poder, de modo que o contraditório ultrapassa a perspectiva meramente formal, envolvendo a indispensável faculdade para que as partes possam exercer efetiva influência no julgamento da causa, o que estaria consagrado, inclusive, em diversos dispositivos do Código de Processo Civil de $1973 .{ }^{151}$

147 NERY JÚNIOR, Nelson. Princípios do processo civil na constituição federal. 5. ed. São Paulo: Revista dos Tribunais, 1999, p. 30-31.

148 WAMBIER, Luiz Rodrigues (Coord.). Curso avançado de processo civil. 2. ed. São Paulo: Revista dos Tribunais, 1999, v. 1, p. 64.

149 CINTRA, Antônio Carlos de Araújo; GRINOVER, Ada Pellegrini; DINAMARCO, Cândido Rangel. Teoria geral do processo. 10. ed. São Paulo: Malheiros, 1994, p. 55-57.

150 OLIVEIRA, Carlos Alberto Álvaro de. O juiz e o princípio do contraditório. Revista de Processo. São Paulo: Revista dos Tribunais, 1994, v. 73, p. 7-14.

151 PORTANOVA, Rui. Princípios do processo civil. 7. ed. Porto Alegre: Livraria do Advogado, 2008, p. 160. 
Volvendo-nos ao texto do Código Buzaid, percebe-se que, para além das regras processuais destinadas a possibilitar a comunicação dos atos processuais e a apresentação de resposta ou manifestação pelas diferentes partes do litígio, a exemplo das alusivas à citação (art. 213), intimações (art. 234), ou produção de prova documental (art. 398), outras há que se prestam a viabilizar a efetiva participação e colaboração das partes para a formação de uma futura decisão judicial.

Nesse sentido, a realização de prova pericial, que admite a indicação de assistente técnico e a oferta de quesitação pelos litigantes (art. 421, § $1^{\circ}$ ), assim como a inspeção judicial, que sempre pode ser acompanhada pelas partes, a quem assiste a faculdade de "prestar os esclarecimentos e fazer as observações que reputem de interesse para a causa" (art. 442, parágrafo único), consistem em atos instrutórios com inegável potencialidade de repercussão no julgamento da demanda, que certamente recebem a influência da parte que venha a participar ativamente da sua produção, destoando qualitativamente de uma prova cuja coleta venha a ser conduzida exclusivamente pelo magistrado.

O mesmo se pode dizer da oitiva de testemunhas, que podem ser arguidas por ambas as partes a respeito dos fatos deduzidos em juízo (art. 416), contribuindo estas diretamente, desse modo, para a formação do conjunto probatório que irá lastrear uma futura decisão a ser proferida, tudo submetido às considerações finais dos figurantes em ambos os polos do processo (art. 454). ${ }^{152}$

Não reputamos correto, portanto, afirmar-se que o modelo de contraditório adotado pelo CPC de 1973 cinge-se ao limitado binômio informação e reação, diante da previsão de diversos meios processuais possibilitadores de uma participação substancial das partes na formação e análise do conjunto probatório e de suas repercussões jurídicas, assegurando-se-lhes, dessa forma, também o direito de influenciar o resultado do julgamento da causa, ao concorrerem para a realização e valoração dos atos processuais, sobretudo os de natureza instrutória.

Isso não significa, porém, que o tratamento conferido ao princípio do contraditório pelo Código (ainda) vigente não possa merecer aperfeiçoamentos, a fim de atribuir maior sintonia e equilíbrio entre os poderes, deveres, ônus e responsabilidades exercidos pelos diferentes sujeitos processuais, dentre os quais insere-se, logicamente, o magistrado.

152 Consigne-se que o novo CPC manteve, em linhas gerais, a disciplina de produção das referidas modalidades probatórias (arts. 465 e 483), evoluindo, de toda sorte, quanto à forma de realização das perguntas às testemunhas, que passam a ser feitas sem o intermédio do juiz, mas apenas sob o controle deste (art. 459). 


\section{O CONTRADITÓRIO COMO GARANTIA DE INFLUÊNCIA E NÃO SURPRESA}

É evidente a implicação paradigmática que o moderno conceito de contraditório acarreta para o Direito Processual Civil, não apenas como vetor teórico, mas sobretudo como um elemento norteador da práxis procedimental, por destinar-se a legitimar, através da participação dos litigantes, a formação do provimento jurisdicional a ser emitido, ao qual estes deverão, ao final, inelutavelmente submeter-se.

Privilegia-se, assim, a posição do jurisdicionado como, simultaneamente, autor e destinatário da ordem jurídica, assegurando-se-lhe a garantia de exercer influência na condução do processo e, consequentemente, na resolução do conflito de interesses, como forma de "controlar os provimentos dos agentes políticos e garantir a legitimidade discursiva e democrática das decisões", abandonando-se os focos de centralidade em qualquer dos sujeitos processuais, seja nas partes ou no juiz, em prol de um modelo policêntrico, ou comparticipativo, de processo. ${ }^{153}$

A relação processual, outrora vista unicamente como cenário de um embate entre autor e réu, mediado pelo magistrado, sob a lógica beligerante da ação e reação, deve passar a ser tratada como uma estrutura eminentemente dialética, na qual o contraditório exerce função central e indispensável, consoante registra José Miguel Garcia Medina, ${ }^{154}$ na esteira do escólio de Elio Fazzalari. ${ }^{155}$

Não se quer, com isso, ignorar o fato de que os litigantes irão invariavelmente orientar sua atuação processual por uma perspectiva estratégica, que tem como escopo a obtenção de êxito em suas respectivas e antagônicas pretensões. É o resultado da intervenção efetiva das partes no processo, contudo, ainda que agindo em defesa exclusiva dos próprios interesses, que irá concorrer com a atuação do órgão jurisdicional para a resolução adequada da lide.

Salientam Humberto Theodoro Júnior, Dierle Nunes, Alexandre Bahia e Flávio Pedron, a esse respeito, que a cooperação processual almejada nesse novo horizonte processual reside na ideia de uma comunidade de trabalho, por meio da qual as partes, agindo na defesa de seus

153 MOTTA, Francisco José Borges; HOMMERDING, Adalberto Narciso. O que é um modelo democrático de processo? Revista do Ministério Público do Rio Grande do Sul. Porto Alegre: AMPRS, n. 73, jan.-abr. 2013, p. 196. Disponível em: <http://www.amprs.org.br/arquivos/revista_artigo/arquivo_1383852047.pdf> Acesso em: 17 jun. 2015. Também: NUNES, Dierle José Coelho. Processo jurisdicional democrático: uma análise crítica das reformas processuais. Curitiba: Juruá, 2008.

154 MEDINA, José Miguel Garcia. A dimensão procedimental dos direitos e o projeto do novo CPC. Revista de Informação Legislativa. Brasília: Senado Federal, n. 190, abr.-jun. 2011, p. 292. Disponível em: <http://www2.senado.leg.br/bdsf/bitstream/handle/id/242899/000923132.pdf?sequence=1> Acesso em: 11 jun. 2015.

155 FAZZALARI, Elio. Istituzioni di diritto processuale, 7. ed. Padova: CEDAM, 1994b, p. 83. 
interesses, possam contribuir para a construção do provimento de forma conjunta com o magistrado, como fruto do que vier a ser produzido em contraditório no processo, seja na reconstrução dos fatos, ou no levantamento de pretensões a direito (reconstrução do ordenamento). ${ }^{156}$

Mostra-se acertada, pois, a lição de Lenio Luiz Streck, Lúcio Delfino, Rafael Giorgio Dalla Barba e Ziel Ferreira Lopes, ao assinalarem a impossibilidade de se pretender atribuir aos litigantes um dever de mútua colaboração processual, objetivando a busca de uma "verdade superior”, em detrimento da própria liberdade de agir, tendo em vista que por comparticipação, na realidade, enquanto garantia de influência e não surpresa, há de se compreender que "cada sujeito já tem seu papel institucionalizado para que possa concorrer, à sua maneira, para a formação do provimento comum". 157

Vislumbram os mencionados autores, ainda, no tocante ao tema, um aporte das autonomias privada e pública de Jürgen Habermas à dogmática processual, colacionando, no mesmo artigo, o diálogo por este travado com Robert Alexy, ao prelecionar que

[...] as limitações específicas, que atingem o agir forense das partes ante o Tribunal, não permite que o evento do processo seja medido pelo discurso racional. As partes não estão obrigadas à busca cooperativa da verdade, uma vez que também podem perseguir seu interesse numa solução favorável do processo "introduzindo estrategicamente argumentos capazes de consenso". Contra isso é possível objetar, com grande plausibilidade, que todos os participantes do processo, por mais diferentes que sejam seus motivos, fornecem contribuições para um discurso, o qual serve, na perspectiva do juiz, para a formação imparcial do juízo. Somente essa perspectiva é constitutiva para a fundamentação da decisão. ${ }^{158}$

A cooperação que se pode exigir das partes, destarte, no âmbito do novo CPC, deve ser entendida como uma atuação processual que, embora pautada pelo dever de boa-fé, nos termos do art. $5^{\circ}$ do referido Código, faculta aos contendores a prática de atos que visem, concomitantemente, a defesa de seus interesses e que se mostrem tendentes a contribuir com o magistrado, na medida da respectiva participação, para a construção do provimento jurisdicional mais adequado ao caso.

Para assegurar a viabilidade do exercício desse denominado poder de influência, passase a erigir em face do julgador uma garantia de não surpresa, no sentido de possibilitar às partes,

156 THEODORO JÚNIOR, Humberto; NUNES, Dierle; BAHIA, Alexandre Melo Franco; e PEDRON, Flávio Quinaud. Op. cit., p. 72.

157 Streck, Lenio Luiz; Delfino, Lúcio; Barba, Rafael Giorgio Dalla; e LOPES, Ziel Ferreira. Aposta na bondade: a cooperação processual do novo CPC é incompatível com a Constituição. Revista Consultor Jurídico, São Paulo, 23 dez. 2014. Disponível em: <http://www.conjur.com.br/2014-dez-23/cooperacao-processual-cpc-incompativelconstituicao> Acesso em: 16 jun. 2015.

158 HABERMAS, Jürgen. Direito e democracia: entre facticidade e validade. Trad. Flavio Beno Siebeneichler. Rio de Janeiro: Tempo Brasileiro, 1997, v. 1, p. 288. 
invariavelmente, manifestar-se previamente sobre toda matéria processualmente relevante, a respeito da qual deva o órgão jurisdicional pronunciar-se na demanda.

Antes mesmo da edição da Lei $n^{\circ}$ 13.105/2015, Fredie Didier Júnior já advertia a respeito do dever de consulta aplicável ao magistrado, como expressão do princípio da cooperação, pelo qual este não pode decidir com base em questão de fato ou de direito - ainda que possa ser conhecida ex officio -, sem que sobre elas sejam as partes intimadas a manifestarse, cumprindo-lhe consultar as partes sobre questão não suscitada anteriormente no processo, antes de exarar decisão, a fim de submetê-la ao crivo do contraditório. Alude o autor, na oportunidade, a disposições legais expressas, no mesmo diapasão, nos Códigos de Processo Civil de Portugal (art. 3º 3), França (art. 16), Itália (art. 101, 2) e Alemanha (§ 139). ${ }^{159}$

Daí porque o legislador brasileiro houve por bem conferir a seguinte redação ao art. 10 do novo CPC: "O juiz não pode decidir, em grau algum de jurisdição, com base em fundamento a respeito do qual não se tenha dado às partes oportunidade de se manifestar, ainda que se trate de matéria sobre a qual deva decidir de ofício".

Para Carlos Alberto Álvaro de Oliveira, o dispositivo não implica em uma superação do brocardo iura novit curia, já que não afeta a liberdade de que dispõe o julgador para eleger a norma aplicável ao caso, independentemente de invocação pela parte, exigindo-se, tão-somente, a prévia ouvida dos litigantes acerca da nova direção a ser dada ao processo, em atenção aos ditames do contraditório. ${ }^{160}$

Trata-se, no dizer de Daniel Mitidiero, de uma mudança de compreensão do próprio direito, a fim de que passe a ser tratado como um problema para cuja solução pode pesar o aporte argumentativo carreado pelas partes ao processo, transitando-se da ideia de processo como solilóquio judicial, para a de um colóquio entre todos os que nele tomam parte. ${ }^{161}$

Tal disposição, no entender do mencionado autor, reforça a confiança das partes no poder jurisidicional do Estado, ao estimular a prolação de uma decisão mais atenta às variadas feições que, em cada caso concreto, possa o problema debatido vir a assumir. ${ }^{162}$

Eleva-se o contraditório, desse modo, a elemento normativo estrutural da comparticipação, a fim de garantir o policentrismo processual e, com isso, permitir aos sujeitos

159 DIDIER JÚNIOR, Fredie. Curso de direito processual civil. 14. ed. Salvador: Juspodivm, 2012, v. 1, p. 91. 160 OLIVEIRA, Carlos Alberto Álvaro de. A garantia do contraditório. Disponível em: <http://www.ufrgs.br/ppgd/doutrina/oliveir1.htm> Acesso em: 11 jul. 2015.

161 MITIDIERO, Daniel. Bases para construção de um processo civil cooperativo: o direito processual civil no marco teórico do formalismo-valorativo, $\quad$ p. $69 . \quad$ Disponível em: <http://www.lume.ufrgs.br/handle/10183/13221> Acesso em: 11 jun. 2015.

162 _. Op. cit., p. 89. 
potencialmente alcançáveis pelos efeitos da decisão judicial contribuir criticamente para sua formação, equilibrando-se os papeis que a todos cabem no processo. ${ }^{163}$

O contraditório, em sua feição contemporânea, apresenta-se a um só tempo como instrumento de legitimação e controle da própria jurisdição e do seu resultado, sendo incompatível com a acepção dinâmica deste princípio constitucional do processo a prolação de decisões-surpresa, porquanto impeditivas da possibilidade de influência dos litigantes sobre a atuação do magistrado e, consequentemente, violadoras do ambiente democrático sob o qual deve ser produzida toda atividade estatal. ${ }^{164}$

Não é por outro motivo que Leonardo Grecco define o princípio do contraditório, hodiernamente, como aquele pelo qual "ninguém pode ser atingido por uma decisão judicial na sua esfera de interesses, sem ter tido a ampla possibilidade de influir eficazmente na sua formação em igualdade de condições com a parte contrária". 165

Essa concepção renovada do contraditório na seara cível resulta, por conseguinte, na necessidade de mudanças no modo de atuação dos sujeitos no processo, bem assim, no próprio desenvolvimento da marcha procedimental, a fim de preparar a causa para julgamento, sujeitando-a ao poder de influência das partes e refletindo, ademais, no próprio conteúdo do ato decisório, do que ora passamos a tratar.

\section{AS CONSEQUÊNCIAS DAS REGRAS DO CONTRADITÓRIO DINÂMICO PARA O ANDAMENTO E O RESULTADO DO PROCESSO NO NOVO CPC}

A Lei $n^{\circ} 13.105 / 2015$ incorporou ao novo estatuto processual algumas orientações já assentadas na doutrina e na jurisprudência quanto à garantia do contraditório, a exemplo da previsão do incidente de desconsideração da personalidade jurídica (arts. 133 a 137), ${ }^{166}$ no qual passou a ser expressamente estabelecida a necessidade de citação do "sócio ou da pessoa

163 THEODORO JÚNIOR, Humberto. O compromisso do projeto de novo código de processo civil com o processo justo. Revista de Informação Legislativa. Brasília: Senado Federal, n. 190, abr.-jun. 2011, p. 247. Disponível em: <http://www2.senado.leg.br/bdsf/bitstream/handle/id/242899/000923132.pdf?sequence=1> Acesso em: 11 jun. 2015.

164 DELFINO, Lúcio. O processo democrático e a ilegitimidade de algumas decisões judiciais. In: ROSSI, Fernando; RAMOS, Glauco Gumerato; GUEDES, Jefferson Carús; DELFINO, Lúcio; MOURÃO, Luiz Eduardo Ribeiro (Org.). O futuro do processo civil no Brasil: uma análise crítica ao projeto do novo CPC. Belo Horizonte: Fórum, 2011, p. 380.

165 GRECCO, Leonardo. Instituições de processo civil: introdução ao direito processual civil. 2. ed. Rio de Janeiro: Forense, 2010, v. 1, p. 540.

166 DELFINO, Lúcio. Op. cit., p. 400. Na perspectiva do direito material, veja-se: GONÇALVES, Carlos Roberto. Direito civil brasileiro. 11. ed. São Paulo: Saraiva, 2013, v. 1, p. 254. 
jurídica”, para manifestação acerca do pedido formulado em seu desfavor (art. 135), no bojo de ação na qual não tenha figurado originalmente como parte.

Outro dispositivo, igualmente significativo, destinado a assegurar o direito ao contraditório no novo Código, diz respeito à hipótese da ocorrência de efeitos infringentes nos embargos de declaração, ao albergar, no seu art. $1.023, \S 2^{\circ}$, a regra que impõe a intimação do embargado para que se pronuncie, no quinquídio, "sobre os embargos opostos, caso seu eventual acolhimento implique a modificação da decisão embargada", adotando-se, no dizer de Cassio Scarpinella Bueno, "com exatidão, o melhor entendimento sobre o assunto". ${ }^{167}$

Tais inovações legislativas, entretanto, apesar de resultarem em maior segurança e estabilidade para o ordenamento processual civil, por força do caráter expresso do texto normativo, limitam-se a refletir uma praxe já consolidada em nosso Direito Processual por meio, sobretudo, da aplicação direta da garantia constitucional do contraditório pelos Tribunais, nas situações aludidas. 168

Diversas e mais profundas, porém, são as consequências processuais da adoção de uma dimensão substancial do princípio do contraditório pelo novo CPC, ao assegurar mais enfaticamente o poder de influência das partes na solução do respectivo conflito de interesses.

Isso porque o contraditório, que outrora era compreendido em uma acepção meramente exterior e formal - anteriormente assinalada - de informação e reação, deve passar, com a novel legislação processual, a repercutir necessariamente, sempre que exercido, no conteúdo do ato decisório. Apresenta-se o dever de fundamentação, nessa perspectiva, como a última manifestação do contraditório, pois de nada adiantaria assegurar o direito de audiência das partes, se pudesse o juiz ignorar solenemente, no ato decisório, a argumentação produzida pelos futuros destinatários do provimento jurisdicional.169

Com efeito, a disposição contida no art. $489, \S 1^{\circ}$, inciso IV, do novo CPC, ao indicar como não fundamentada - e, portanto, passível de nulidade, ex vi do art. 93, inciso IX, da Constituição Federal - a decisão judicial que "não enfrentar todos os argumentos deduzidos no processo capazes de, em tese, infirmar a conclusão adotada pelo julgador”, impõe que seja dada

167 BUENO, Cassio Scarpinella. Novo Código de Processo Civil anotado. São Paulo: Saraiva, 2015, p. 660. 168 Veja-se a propósito, a orientação do Superior Tribunal de Justiça (STJ) acerca da temática, ao decidir que "a atribuição de efeitos infringentes aos embargos de declaração é um consectário lógico do suprimento de um dos vícios previstos na lei [...] que, ao ser sanado, pode acarretar a modificação da conclusão do julgado, devendo ser respeitado o contraditório", consoante julgado emitido pela Sexta Turma, em 06 jun. 2013 , Relator o Ministro Sebastião Reis Júnior, nos autos dos Embargos de Declaração no Agravo Regimental no Recurso Especial $\quad \mathrm{n}^{\circ} \quad 1161403 / \mathrm{RS}$ Disponível em: <https://ww2.stj.jus.br/processo/revista/inteiroteor/?num_registro=200901979241\&dt_publicacao=21/06/2013>. Acesso em: 02 jul. 2015.

169 WAMBIER, Teresa Arruda Alvim. Omissão judicial e embargos de declaração. São Paulo: Revista dos Tribunais, 2005, p. 389. 
a devida significação ao exercício do contraditório, reclamando um atento exame, pelo julgador, das razões apresentadas pelas partes, no que guardem pertinência com os fundamentos necessários à resolução do conflito de interesses. ${ }^{170}$

A motivação contida na sentença deve considerar seriamente os argumentos deduzidos pelas partes no processo, porém isso não pode implicar em uma exigência excessiva de enfrentamento, pelo juiz, de toda e qualquer asserção formulada pelos litigantes, ainda que desprovida de correlação plausível com o objeto da causa, pois tal entender culminaria, decerto, mesmo por inviabilizar o andamento racional do processo.

O que se exige, outrossim, é que o órgão jurisdicional exare o pronunciamento decisório mantendo um verdadeiro diálogo com os demais sujeitos processuais, construindo a solução jurídica do caso concreto a partir das balizas argumentativas advindas da dialética gerada pela correspondente comunidade de trabalho, em substituição a um raciocínio monológico doravante considerado insatisfatório -, que por vezes impera na seara da prática judicial. ${ }^{171}$

Não pode dita regra processual, advirta-se, transformar-se em instrumento de prevalência de mais um óbice de índole formal no processo civil brasileiro, destinado unicamente a forçar o julgador ao cumprimento de um requisito meramente ritual no ato de julgar, sob pena de, não o fazendo, cair na armadilha da nulidade processual. E, para tanto, sempre haverá aqueles que, enquanto interessados no retardamento máximo do deslinde da problemática deduzida em juízo, trarão para o processo o maior número imaginável de argumentos, tanto mais complexos ou rebuscados quanto se mostrar possível, a fim de semear a eiva da nulidade a ser artificialmente cultivada.

Esse não é, manifestamente, o propósito almejado pelo legislador ao consagrar o contraditório dinâmico no novel diploma instrumental civil, orientado pelo espírito de cooperação que deve animar a atuação dos sujeitos processuais. ${ }^{172}$

Assim é que os arts. $4^{\circ}$ a $6^{\circ}$ da Lei $n^{\circ} 13.105 / 2015$, em harmonia com o texto constitucional, prestigiam a duração razóavel do processo, cabendo aos que dele participam pautar-se de acordo com a boa-fé, que de todos se espera.

A prática do contraditório, conquanto se apresente como meio bastante de legitimação da prestação jurisdicional entregue pelo Estado, não pode ser legalmente regida de modo a

170 THEODORO JÚNIOR, Humberto; NUNES, Dierle; BAHIA, Alexandre Melo Franco; e PEDRON, Flávio Quinaud. Op. cit., p. 102.

171 MITIDIERO, Daniel. Op. cit., p. 103.

172 THEODORO JÚNIOR, Humberto; NUNES, Dierle; BAHIA, Alexandre Melo Franco; e PEDRON, Flávio Quinaud. Op. cit., p. 72. 
favorecer a veiculação de atitudes maliciosas no processo e, consequentemente, a agasalhar o exercício abusivo de direitos. ${ }^{173}$

Ora, se a sentença há de apreciar, necessariamente, todas as alegações aventadas pelos litigantes, igualmente deve caber a estes, correlatamente, deduzir seus argumentos de forma minimamente responsável, objetivando colaborar com o órgão judicial para alcançar uma solução adequada para o conflito de interesses, ainda que as partes o façam visando, naturalmente, a prevalência de seus próprios interesses. Só quando verdadeiramente imbuídos desse propósito cooperativo poderão os contendores exigir o exame, pelo juiz, das correspondentes alegações suscitadas no feito. ${ }^{174}$

Essa, aliás, é a orientação consoante a ideia de formalismo-valorativo, informado pela lealdade e pela boa-fé, a reclamar a cooperação do órgão judicial com as partes e destas com aquele. $^{175}$

Implicará, portanto, em violação à regra do art. $5^{\circ}$ do novo Código de Processo Civil, pela qual "aquele que de qualquer forma participa do processo deve comportar-se de acordo com a boa-fé", o comportamento do litigante que, buscando obstaculizar o normal andamento da causa, vier a sustentar múltiplas argumentações nitidamente impertinentes ou destituídas de embasamento jurídico, com o intuito velado de vir a arguir a nulidade da decisão que deixar de enfrentar todas essas alegações, ainda que propositadamente infundadas.

Submete-se tal sujeito processual, consequentemente, tanto às sanções reservadas à litigância de má-fé, descritas nos arts. 79 a 81 do novo Código - que restaram consideravelmente intensificadas em relação ao CPC de $1973-,{ }^{176}$ quanto à concessão da tutela de evidência em favor da parte contrária, como resposta ao abuso do direito de defesa ou manifesto propósito protelatório a ser verificado no caso concreto, na forma do art. 311, inciso I, do mesmo diploma processual. E nisso o Poder Judiciário há que ser firme e determinado, ao

173 PINHO, Humberto Dalla Bernardina de; ALVES, Tatiana Machado. A cooperação e a principiologia no processo civil brasileiro: uma proposta de sistematização. Revista Eletrônica de Direito Processual, ano 7, v. 12, jul.-dez. 2013, p. 306. Disponível em: <http://www.redp.com.br/edicao_12.htm>. Acesso em: 16 jun. 2015.

174 PEREIRA COITINHO, Jair. Verdade e colaboração no processo civil. Disponível em: <http://www.ambitojuridico.com.br/site/index.php?n_link=revista_artigos_leitura\&artigo_id=8042\#_ftn126>. Acesso em 03 jul. 2015 .

175 OLIVEIRA, Carlos Alberto Alvaro de. O Formalismo-valorativo no confronto com o formalismo excessivo. In: DIDIER JÚNIOR, Fredie (Org.). Leituras complementares de processo civil. 5. ed., rev. e ampl. Salvador: Jus Podivm, 2007, p. 368.

176 D'ORIO, Rodrigo. Sanções penitenciais no projeto do novo CPC. In: ROSSI, Fernando; RAMOS, Glauco Gumerato; GUEDES, Jefferson Carús; DELFINO, Lúcio; MOURÃO, Luiz Eduardo Ribeiro (Org.). O futuro do processo civil no Brasil: uma análise crítica ao projeto do novo CPC. Belo Horizonte: Fórum, 2011, p. 534537. 
constatar a ocorrência de exercício abusivo das faculdades processuais pela parte, sob pena de tornar letra morta o sobredito dever de boa-fé processual.

Seria ingenuidade afirmar, de todo modo, que não haverá espaço no ambiente processual vindouro para artifícios destinados a provocar maliciosamente a ocorrência da causa de nulidade prevista no art. $489, \S 1^{\circ}$, inciso IV, do novo CPC. É inegável que muitos litigantes buscarão meios para, com habilidade, complexificar sua argumentação, ou aduzir teses jurídicas pretensamente inovadoras, mas que não possam, por outro lado, vir a ser consideradas manifestamente protelatórias, a fim de dificultar - e consequentemente postergar - o julgamento da demanda.

A despeito do tema suscitar indagações que exorbitam os limites e o propósito do presente ensaio, havendo larga margem para investigação doutrinária e manifestação jurisprudencial, pode-se afirmar, de toda sorte, que a definição do objeto litigioso, quando do saneamento processual, exercerá papel fundamental para a fixação do thema decidendum e, consequentemente, para o exercício dos ônus e faculdades inerentes ao contraditório, que os litigantes devem cumprir no processo, como forma de organização prospectiva deste. ${ }^{177}$

Impõe-se, assim, que se leve a sério a etapa preparatória da fase de conhecimento, pois a fixação exaustiva, pelo juiz, mediante o auxílio e colaboração das partes (art. 357 do novo CPC), das questões constitutivas do objeto de cognição processual, servirá para implementar "a baliza discursiva necessária (contraditório) para o debate participativo", ${ }^{178}$ como forma de definir os pontos a respeito dos quais deverá o julgador pronunciar-se quando da decisão da causa, sob pena de nulidade.

E nisso, uma vez mais, a participação das partes em contraditório revela-se essencial, cabendo-lhes "pedir esclarecimentos ou solicitar ajustes", em relação à decisão saneadora que vier a delimitar "as questões de fato sobre as quais recairá a atividade probatória", assim como as "questões de direito relevantes para a decisão do mérito", nos termos do art. $357, \S 1^{\text {o }}$, da nova lei processual. Em permanecendo os litigantes inertes, na dicção do mesmo dispositivo, “a decisão se torna estável”.

Significa dizer, enfim, que caso desejem as partes ver os seus argumentos apreciados na sentença, deverão demonstrar a sua relevância desde o momento do saneamento processual, a fim de que constem como matéria fática ou jurídica a ser tratada na causa, seja na própria decisão senadora - ofertando, para tanto, a postulação cabível -, seja formulando-o

177 MITIDIERO, Daniel. Op. cit., p. 86.

178 THEODORO JÚNIOR, Humberto; NUNES, Dierle; BAHIA, Alexandre Melo Franco; e PEDRON, Flávio Quinaud. Op. cit., p. 113-114. 
consensualmente com o polo adverso ( $\operatorname{art} .357, \S 2^{\circ}$ ), pois do contrário o assunto precluirá, não podendo sequer ser objeto de questionamento preliminar do apelo ou das contrarrazões, consoante dispõe o $§ 1^{\circ}$ do art. 1.009 do novo CPC. ${ }^{179}$

Não resta dúvida, porém, que a intensificação da importância da fase saneadora para o deslinde processual e, até mesmo, para o julgamento ulterior da causa, não obstante deva acarretar, se levada a bom termo, uma melhor qualificação da demanda, implicará na necessidade de ser despendido nessa etapa maior tempo e energia dos sujeitos processuais sobretudo do magistrado - em comparação ao sistema do Código Buzaid.

É inequívoco, como se pode perceber, que a feição marcadamente mais dinâmica atribuída pelo novo Código de Processo Civil ao princípio do contraditório visa consolidar a democratização do processo brasileiro, ao possibilitar uma participação mais substancial dos litigantes na formação cooperativa do provimento jurisdicional. Não se pode negar, todavia, os reflexos potencialmente negativos que daí decorrerão para a duração do feito, em razão da elevação do nível de exigência que passa a cercar o exercício da atividade judicante não apenas no ato de sentenciar, mas também em suas etapas preparatórias, no que diz respeito ao amadurecimento da causa por meio do constante diálogo com as partes.

Uma vez posta a nova legislação processual, cujos ganhos qualitativos para o resultado do processo dependerão grandemente, por óbvio, do uso que venha a ser feito das inovações legais, resta confiar que a tarefa de reconstrução do Direito, a ser exercida pela doutrina e jurisprudência venha a lograr, igualmente, o alcance de razoável equilíbrio entre a busca pela correção do julgamento e os valores da celeridade e efetividade processuais, a fim de que o recente estatuto normativo possa corresponder minimamente aos anseios de jurisdicionados e profissionais da área jurídica.

\section{CONSIDERAÇÕES FINAIS}

O novo Código de Processo Civil surge como pretensa resposta estatal aos reclamos sociais por uma prestação jurisdicional mais célere, racional e efetiva, em uma época marcada pelos questionamentos quanto ao papel que a função jurisdicional deve exercer para a formação do Direito e, outrossim, acerca da forma de incidência dos princípios jurídicos para a solução das controvérsias, pela massificação dos conflitos, pelo advento de novos meios de 
comunicação e documentação dos atos processuais, apesar da existência de uma legislação processual vigente tecnicamente elogiável, submetida nos últimos vinte anos a festejadas reformas.

Uma das características mais proeminentes do novo Código consiste na renovação do tratamento legal conferido à garantia constitucional do contraditório, que passa a ocupar lugar central no ambiente processual, dando-se maior ênfase à faculdade das partes de exercer real influência para a formação do provimento judicial, como forma de controle dessa manifestação de poder estatal e, em última análise, de legitimação do exercício da jurisdição.

O princípio do contraditório passa, assim, a assentar suas bases na dialética que norteia o desenvolvimento dos atos processuais, mediante a cooperação processual que deve existir entre as partes e o juiz, a constituir uma comunidade de trabalho orientada pelo policentrismo processual, assegurando-se aos litigantes, notadamente, a possibilidade de contribuir para a construção de uma solução para a causa de forma conjunta com o magistrado.

Veda-se, para tanto, como presssuposto necessário, a prolação das chamadas decisõessurpresa, em um aprofundamento dos mecanismos já existentes no estatuto processual de 1973, superando qualquer resquício de uma concepção meramente lógico-formal de contraditório, como simples direito de bilateralidade de audiência.

Além de haver suprido lacunas legislativas existentes no Código Buzaid, regulamentando o incidente de desconsideração da personalidade jurídica, para assegurar o exercício do contraditório pelos potenciais atingidos pela decisão judicial (art. 135), ou ao garantir o mesmo direito, também, na hipótese da concessão de efeitos infringentes aos embargos de declaração (art. 1.023, $\S 2^{\circ}$ ), notabiliza-se o novo Código de Processo Civil, sobretudo, pela nova dimensão atribuída ao princípio constitucional que intitula este trabalho.

O contraditório não mais deve ser tratado como simples formalidade destituída de um fim substancial, pois o seu real escopo reside em assegurar aos destinatários do poder jurisdicional do Estado a faculdade de exercer influência na solução do conflito de interesses, o que não se esgota na mera prática de atos processuais pelos litigantes, mas tem o condão, sobretudo, de repercutir no momento decisório propriamente dito.

Essa é a razão pela qual o art. $489, \S 1^{\circ}$, inciso IV, do novo CPC erige como requisito da sentença, sob pena de nulidade, que enfrente todos os argumentos deduzidos no processo capazes de, em tese, infirmar a conclusão adotada pelo magistrado.

Cabe ao julgador, destarte, considerar seriamente os argumentos formulados pelas partes, sem que isso implique, contudo, em uma exigência excessiva, em face do juiz, de profunda apreciação de toda e qualquer asserção formulada pelos litigantes, ainda que 
desprovida de correlação plausível com o objeto da causa, devendo os sujeitos processuais pautarem-se, também quanto a esse aspecto, pelos ditames do formalismo-valorativo, norteado pela lealdade e boa-fé, no sentido da cooperação do órgão judicial com as partes e destas com aquele.

Como parâmetro seguro para demarcar a matéria a respeito da qual devem ser travados os debates processuais e que, por esse motivo, deverá, consequentemente, constituir o objeto da decisão judicial, o novo Código elegeu a etapa de saneamento da demanda, cuja importância eleva-se significativamente, se comparada ao diploma processual ainda vigente.

Ao estabelecer que o juiz, por ocasião do saneamento do processo, deve delimitar não só "as questões de fato sobre as quais recairá a atividade probatória", mas também as "questões de direito relevantes para a decisão do mérito", em decisão que, após eventuais pedidos de esclarecimentos ou ajustes formulados pelas partes, torna-se estável, o art. 357 do novo CPC impõe ao magistrado, de um lado, o dever de consultar os demais sujeitos processuais acerca de eventual aspecto que só ulteriormente venha a ser constatado como relevante para o deslinde da causa e às partes, de outro, o ônus de suscitar todas as matérias essenciais nos momentos processuais adequados.

Uma vez desatendido tal dever de consulta pelo juiz, ao decidir acerca de questão não debatida pelos litigantes no processo ou, ainda, que não conste dentre as delimitadas na decisão saneadora, viola-se a regra proibitiva de decisão surpresa, ainda que se trate de matéria sobre a qual deva decidir de ofício (art. 10 do novo Código), em uma releitura da máxima iura novit curia, a fim de garantir às partes o exercício do poder de influência na formação do provimento judicial.

A decisão senadora passa a figurar, portanto, como um instrumento de verdadeira organização prospectiva do processo, viabilizador do exercício, de forma clara e objetiva, das faculdades, ônus e deveres inerentes a todos que o integram, para que possam deles desincumbir-se a contento, a fim de evitar, inclusive, a prática de atos que possam se tornar eivados de nulidade.

Espera-se, assim, que a doutrina e a jurisprudência venham a encontrar um caminho que, rechaçando comportamentos abusivos, permitam ao Poder Judiciário atender a promessa de celeridade na entrega da prestação jurisdicional, sem resultar, porém, em julgamentos açodados, violadores do direito ostentado pela parte de se fazer efetivamente ouvida pelo julgador - e, assim, poder influir na decisão -, nem muito menos em acolhimento de nulidades provocadas pela atuação maliciosa de quem não deseja uma solução para a contenda, mas sim retardá-la o quanto possa. 
Consagra o novo Código de Processo Civil, desse modo, a garantia constitucional do contraditório, compreendido em sua acepção contemporânea como poder de influência e não surpresa, como meio de legitimação endoprocessual da função jurisdicional do Estado e como mecanismo de controle, pelos demais sujeitos processuais, dos provimentos judiciais aos quais deverão as partes, ao final, submeter-se.

Impõe-se, contudo, que as inovações legislativas sejam aplicadas em consonância com os ditames do formalismo-valorativo, privilegiando-se a boa-fé e a lealdade processuais e coibindo-se, veementemente, as tentativas de desvirtuamento procrastinatório que certamente advirão no ambiente forense, em face das disposições do novo Código.

\section{REFERÊNCIAS}

BRASIL. Código de Processo Civil. Lei n ${ }^{\circ}$ 5.869, de 11 de janeiro de 1973. Diário Oficial [da] República Federativa do Brasil, Poder Executivo, Brasília, DF, 17 jan. 1973, p. 1.

Código de Processo Civil. Lei no 13.105, de 16 de março de 2015. Diário Oficial [da] República Federativa do Brasil, Poder Executivo, Brasília, DF, 17 mar. 2015, Seção 1, p. 1.

Congresso Nacional. Senado Federal. Comissão de Juristas. Anteprojeto do novo Código de Processo Civil. Brasília: Senado Federal, 2010, p. 13. Disponível em: $<$ http://www.senado.gov.br/senado/novocpc/pdf/Anteprojeto.pdf>. Acesso em: 05 jun. 2015.

Superior Tribunal de Justiça. (6 $6^{a}$ Turma). Embargos de Declaração no Agravo Regimental no Recurso Especial n ${ }^{\circ}$ 1161403/RS, Rel. Min. Sebastião Reis Júnior. Brasília, 06 jun. 2013, Dje 21 jun. 2013. Disponível em: <https://ww2.stj.jus.br/processo/revista/inteiroteor/?num_registro=200901979241\&dt_publica cao=21/06/2013>. Acesso em: 02 jul. 2015.

BUENO, Cassio Scarpinella. Novo Código de Processo Civil anotado. São Paulo: Saraiva, 2015.

- Bases para um pensamento contemporâneo do direito processual civil. In: CARNEIRO, Athos Gusmão; CALMON, Petrônio (org.). Bases científicas para um renovado direito processual. 2 ed. Salvador: Jus Podium, 2009.

CAPPELlETTI, Mauro; GARTH, Bryant. Acesso à justiça. Trad. Ellen Gracie Northfleet. Porto Alegre: Sérgio Antonio Fabris Editor, 1988. 
CINTRA, Antônio Carlos de Araújo; GRINOVER, Ada Pellegrini; DINAMARCO, Cândido Rangel. Teoria geral do processo. 10. ed. São Paulo: Malheiros, 1994.

DELFINO, Lúcio. O processo democrático e a ilegitimidade de algumas decisões judiciais. In: ROSSI, Fernando; RAMOS, Glauco Gumerato; GUEDES, Jefferson Carús; DELFINO, Lúcio; MOURÃO, Luiz Eduardo Ribeiro (Org.). O futuro do processo civil no Brasil: uma análise crítica ao projeto do novo CPC. Belo Horizonte: Fórum, 2011.

DIDIER JÚNIOR, Fredie. Curso de direito processual civil. 14. ed. Salvador: Juspodivm, 2012, v. 1.

'ORIO, Rodrigo. Sanções penitenciais no projeto do novo CPC. In: ROSSI, Fernando; RAMOS, Glauco Gumerato; GUEDES, Jefferson Carús; DELFINO, Lúcio; MOURÃO, Luiz Eduardo Ribeiro (Org.). $O$ futuro do processo civil no Brasil: uma análise crítica ao projeto do novo CPC. Belo Horizonte: Fórum, 2011, p. 534-537.

FAZZALARI, Elio. Istituzioni di diritto processuale, 7. ed. Padova: CEDAM, 1994b, p. 83.

GONÇALVES, Carlos Roberto. Direito civil brasileiro. 11. ed. São Paulo: Saraiva, 2013, v. 1 .

GRINOVER, Ada Pellegrini. O magistério de Enrico Tullio Liebman no Brasil. Revista da Faculdade de Direito da Universidade de São Paulo. São Paulo: Universidade de São Paulo, v. $1,1986$.

GRECCO, Leonardo. Instituições de processo civil: introdução ao direito processual civil. 2. ed. Rio de Janeiro: Forense, 2010, v. 1

HABERMAS, Jürgen. Direito e democracia: entre facticidade e validade. Trad. Flavio Beno Siebeneichler. Rio de Janeiro: Tempo Brasileiro, 1997, v. 1.

MARINONI, Luiz Guilherme. Ideias para um renovado direito processual. In: CARNEIRO, Athos Gusmão; CALMON, Petrônio (org.). Bases científicas para um renovado direito processual. 2 ed. Salvador: Jus Podium, 2009. 
MEDINA, José Miguel Garcia. A dimensão procedimental dos direitos e o projeto do novo CPC. Revista de Informação Legislativa. Brasília: Senado Federal, n. 190, abr.-jun. 2011. Disponível em: <http://www2.senado.leg.br/bdsf/bitstream/handle/id/242899/000923132.pdf?sequence=1> Acesso em: 11 jun. 2015.

MITIDIERO, Daniel. Bases para construção de um processo civil cooperativo: o direito processual civil no marco teórico do formalismo-valorativo. Disponível em: <http://www.lume.ufrgs.br/handle/10183/13221> Acesso em: 11 jun. 2015.

MOTTA, Francisco José Borges; HOMMERDING, Adalberto Narciso. O que é um modelo democrático de processo? Revista do Ministério Público do Rio Grande do Sul. Porto Alegre: AMPRS, n. 73, jan.-abr. 2013. Disponível em: <http://www.amprs.org.br/arquivos/revista_artigo/arquivo_1383852047.pdf> Acesso em: 17 jun. 2015.

NERY JÚNIOR, Nelson. Princípios do processo civil na constituição federal. 5. ed. São Paulo: Revista dos Tribunais, 1999.

NUNES, Dierle José Coelho. Processo jurisdicional democrático: uma análise crítica das reformas processuais. Curitiba: Juruá, 2008.

OLIVEIRA, Carlos Alberto Álvaro de. A garantia do contraditório. Disponível em: <http://www.ufrgs.br/ppgd/doutrina/oliveir1.htm> Acesso em: 11 jul. 2015.

O juiz e o princípio do contraditório. Revista de Processo. São Paulo: Revista dos Tribunais, 1994, v. 73.

O Formalismo-valorativo no confronto com o formalismo excessivo. In: DIDIER JÚNIOR, Fredie (Org.). Leituras complementares de processo civil. 5. ed., rev. e ampl. Salvador: Jus Podivm, 2007.

PEREIRA COITINHO, Jair. Verdade e colaboração no processo civil. Disponível em: $<$ http://www.ambitojuridico.com.br/site/index.php?n_link=revista_artigos_leitura\&artigo_id=8042\#_ftn126>. Acesso em 03 jul. 2015.

PORTANOVA, Rui. Princípios do processo civil. 7. ed. Porto Alegre: Livraria do Advogado, 2008. 
PINHO, Humberto Dalla Bernardina de; ALVES, Tatiana Machado. A cooperação e a principiologia no processo civil brasileiro: uma proposta de sistematização. Revista Eletrônica de Direito Processual, ano 7, v. 12, jul.-dez. 2013. Disponível em: <http://www.redp.com.br/edicao_12.htm>. Acesso em: 16 jun. 2015.

Streck, Lenio Luiz; Delfino, Lúcio; Barba, Rafael Giorgio Dalla; e LOPES, Ziel Ferreira. Aposta na bondade: a cooperação processual do novo CPC é incompatível com a Constituição. Revista Consultor Jurídico, São Paulo, 23 dez. 2014. Disponível em: $<$ http://www.conjur.com.br/2014-dez-23/cooperacao-processual-cpc-incompativelconstituicao> Acesso em: 16 jun. 2015.

THEODORO JÚNIOR, Humberto. O compromisso do projeto de novo código de processo civil com o processo justo. Revista de Informação Legislativa. Brasília: Senado Federal, n. 190, abr.-jun. 2011, p. 247.2 Disponível em: <http://www2.senado.leg.br/bdsf/bitstream/handle/id/242899/000923132.pdf?sequence=1> Acesso em: 11 jun. 2015.

; NUNES, Dierle; BAHIA, Alexandre Melo Franco; PEDRON, Flávio Quinaud. Novo CPC: fundamentos e sistematização. 2. ed. Rio de Janeiro: Forense, 2015.

WAMBIER, Luiz Rodrigues (Coord.). Curso avançado de processo civil. 2. ed. São Paulo: Revista dos Tribunais, 1999, v. 1.

WAMBIER, Teresa Arruda Alvim. Omissão judicial e embargos de declaração. São Paulo: Revista dos Tribunais, 2005.

\title{
THE CONSTITUTIONAL GUARANTEE OF CONTRADICTORY ON THE NEW PROCEDURAL SYSTEM
}

\begin{abstract}
This article examines the constitutional guarantee of contradictory, as remains conformed in the new brazilian Civil Procedure Code, passing as a necessary antecedent for the analysis of the main scopes that enlivened reformer work of the legislature in the face of the civil statute of 1973 . Will be exposed, then, about the theoretical outlines until then attributed to that constitutional principle in the civil sphere, describing, finally, the most important and substantive changes implemented by Law $\mathrm{N}^{\circ}$. 13,105/15, by introducing the dynamic contradictory as a guarantee of influence and no surprise, on the new procedural system.
\end{abstract}


Keywords: Contradictory. Assurance influence. No surprise. New brazilian Civil Procedure Code. 